\title{
PENGARUH KUALITAS MAKANAN DAN KEWAJARAN HARGA TERHADAP KEPUASAN PELANGGAN GENERASI MILENIAL SELAMA MASA PANDEMI COVID-19
}

\author{
THE EFFECT OF FOOD QUALITY AND PRICE FAIRNESS ON \\ MILLENIAL GENERATIONS CUSTOMER SATISFACTION DURING \\ THE COVID-19 PANDEMIC PERIOD
}

\author{
Nonot Yuliantoro $^{1) *}$, Erinna Gracia ${ }^{2)}$, Jessica Novia ${ }^{3)}$ \\ ${ }^{1)}$ Fakultas Pariwisata - Universitas Pelita Harapan \\ ${ }^{2)}$ Fakultas Pariwisata - Universitas Pelita Harapan \\ ${ }^{3)}$ Fakultas Pariwisata - Universitas Pelita Harapan
}

Diterima 10 Mei 2021 /Disetujui 28 Mei 2021

\begin{abstract}
The purpose of this study was to analyze and examine the effect of food quality and the fairness of the XYZ restaurant prices in Alam Sutera on the customer satisfaction of the millennial generation. This research is a quantitative study using a survey method. In this study, the population is the millennial generation who live in the Tangerang and Jakarta area with a vulnerable age of 18-38 years as customers at XYZ Alam Sutera Restaurant. The sample was taken randomly as many as 200 respondents with online purposive sampling technique. Data collection was carried out during the COVID-19 pandemic using a Likert scale 1-5 instrument. The data analysis technique used instrument test, descriptive analysis, hypothesis testing using validity test, reliability test, determination coefficient test, $T$ test and $F$ test as well as multiple linear regression, classical assumption test. The data obtained were analyzed through the SPSS version 25.0 program. The results of this study indicate that food quality has a significant positive effect on customer satisfaction. A significant positive relationship also exists in price reasonableness and customer satisfaction.
\end{abstract}

Keywords: Food Quality, Price Fairness, Customer Satisfaction, Millennial Generation.

\section{ABSTRAK}

Tujuan penelitian ini untuk menganalisa dan menguji pengaruh kualitas makanan dan kewajaran harga restoran XYZ di Alam Sutera mempengaruhi kepuasan pelanggan generasi milenial. Penelitian ini merupakan penelitian kuantitatif dengan metode survey. Dalam penelitian ini populasinya merupakan generasi milenial yang berdomisili di area Tangerang dan Jakarta dengan rentan usia 18-38 tahun sebagai pelanggan di Restoran XYZ Alam Sutera. Sampel diambil secara acak sebanyak 200 responden dengan teknik purposive sampling secara daring. Pengumpulan data dilakukan selama masa pandemi COVID-19 dengan instrumen skala Likert 1-5. Teknik analisis data menggunakan uji instrumen, analisis deskriptif, pengujian hipotesis dengan menggunakan uji validitas, uji reliabilitas, uji koefisien determinasi, uji $\mathrm{T}$ dan uji $\mathrm{F}$ serta regresi linear berganda, uji asumsi klasik. Data yang diperoleh dianalisis melalui program SPSS versi 25.0. Hasil penelitian ini menunjukkan bahwa kualitas makanan berpengaruh positif signifikan terhadap kepuasan pelanggan. Hubungan positif yang signifikan juga terdapat pada kewajaran harga dan kepuasan pelanggan.

Kata kunci : Kualitas Makanan, Kewajaran Harga, Kepuasan Pelanggan, Generasi Milenial.

\section{PENDAHULUAN}

A. Latar Belakang

Pada era globalisasi ini menunjukkan bahwa sektor pariwisata berkembang pesat, salah satunya adalah industri makanan. Menurut (Hirschberg, C., Rajko, A., Schumacher, T. \&
Wrulich, 2016) "sebuah bisnis industri harus memiliki kemampuan untuk beradaptasi dengan perubahan teknologi agar dapat beroperasi secara maksimal." Bisnis industri makanan dapat dikatakan sebagai bisnis khusus yang selalu mengungsung konsep 
menarik bagi para konsumen dengan beradaptasi pada setiap perubahan teknologi. Menurut (Yeo et al., 2017)“beberapa bisnis telah terdorong untuk meningkatkan layanan mereka agar bisa menyesuaikan diri dengan kompetitor." Dari makanan hingga jasa, setiap industri makanan yang berbeda telah menciptakan konsep kreatif dan konsep unik masing-masing. Menurut (Menteri Pariwisata dan Ekonomi Kreatif Republik Indonesia Nomor 11 Tahun 2014), Restoran merupakan "jenis usaha jasa dalam bidang pangan yang berada di dalam sebuah bangunan dilengkapi dengan peralatan dan perlengkapan untuk memudahkan proses penjualan makanan dan minuman di tempat umum sesuai ketentuan usaha."

Seiring perkembangan zaman, maka munculnya restoran-restoran baru yang memiliki ciri khas atau keunikannya masingmasing telah meningkatkan jumlah produk ataupun jasa yang diberikan. Kenaikan jumlah restoran-restoran baru tersebut diiringi dengan peningkatan daya beli masyarakat sesuai dengan daya tarik masyarakat Indonesia terutama masyarakat yang termasuk sebagai Baby Boomers dan Generasi $\mathrm{X}$, yang memiliki gaya hidup selaras dengan kondisi saat ini dan generasi ini lahir pada tahun 1982-2002 (Howe, N \& Strauss, 2000). Generasi milenial merupakan bagian dari kelompok sosial yang selalu menyesuaikan gaya hidup terkini dengan mencoba hal baru dan juga restoran-restoran baru.

Berawal sejak Januari tahun 2020, wabah COVID-19 berkembang cukup pesat dalam setiap negara berkembang salah satunya yakni Indonesia. Dalam jangka waktu singkat, COVID-19 ini mampu memicu kekhawatiran krisis ekonomi karena adanya "pemberlakuan jarak sosial (social distancing), isolasi diri, dan pembatasan perjalanan yang mengakibatkan pengurangan tenaga kerja di semua sektor ekonomi." (Nicola et al., 2020) Penelitian ini diadopsi dari penelitian sebelumnya dengan meneliti dampak dari variabel kualitas makanan (food quality), kewajaran harga (price fairness), dan lingkungan fisik (physical environment) yang akan diuji pengaruhnya terhadap kepuasan pelanggan (customer satisfaction) (Jalal Hanaysha, 2016) dengan mengembangkan variabel kualitas makanan (food quality) dan kewajaran harga (price fairness) yang dirasakan sebagai faktor yang mempengaruhi variabel kepuasan pelanggan (customer satisfaction) generasi milenial pada masa pandemi COVID-19.

\section{B.Tinjauan Pustaka dan Hipotesis}

\section{Hubungan Kualitas Makanan dengan Kepuasan Pelanggan}

Kualitas makanan dideskripsikan sebagai konsep yang digunakan untuk mengevaluasi produk atau layanan baik sebelum dan sesudah penggunaannya (Chamhuri \& Batt, 2015) Kualitas makanan juga dapat dikatakan sebagai sebuah aspek esensial yang dapat mempengaruhi pengalaman konsumen dalam membeli makanan (Sjahroeddin \& Administrasi, 2018). Faktor kualitas makanan yang mempengaruhi kepuasan pelanggan yaitu; Presentation offood, Taste, Diversity of choice, Healthy, Freshness, Temperature (Jalal Hanaysha, 2016). Menurut (Ehsani \& Ehsani, 2015)'kualitas produk memainkan peran kunci dalam daya saing perusahaan dengan mempengaruhi kepuasan pelanggan, kualitas produk telah diakui juga sebagai penentu dari sebuah perilaku

pembelian dan kepuasan pelanggan yang ditentukan oleh kinerja dan ekspektasi, yang juga akan berdampak kepada kesuksesan perusahaan.”. Pada penelitian yang dilakukan oleh (Yuliantoro et al., 2019) menyatakan adanya pengaruh signifikan kualitas makanan terhadap kepuasan pelanggan. Berdasarkan penelitian sebelumnya, didapatkan hipotesis berikut:

H1 Kualitas makanan memiliki pengaruh yang signifikan terhadap kepuasan pelanggan

\section{Hubungan Kewajaran Harga dengan Kepuasan Pelanggan}

Kewajaran harga adalah jumlah nominal yang harus dikeluarkan untuk mendapatkan suatu produk atau layanan tertentu (Lien et al., 2015) akan tetapi tidak mudah bagi konsumen untuk dapat menilai kewajaran harga dengan membandingkan produk yang sama atau mirip dengan harga yang berbedabeda(Rothenberger, 2015) Terdapat beberapa faktor yang mempengaruhi variabel kewajaran harga, yaitu; Offered price of $a$ 
product or service, reasonable, cost of good sold, competitors price (Xia et al., 2004; Bolton et al., 2003; Briesch et al., 1997; Hanaysha, 2016). Menurut (Andaleeb \& Conway, 2006; Quang et al., 2018) faktor yang mempengaruhi kepuasan pelanggan di restoran adalah kualitas pelayanan, kualitas makanan dan minuman, harga yang bersahabat. Kewajaran harga memiliki berpengaruh terhadap kepuasan pelanggan secara positif dan signifikan ((Jalal Hanaysha, 2016). Didukung juga dengan penelitian yang dilakukan oleh (Yuliantoro et al., 2019) bahwa variabel kewajaran harga secara parsial berpengaruh positif terhadap kepuasan pelanggan. Berdasarkan penelitian sebelumnya, didapatkan hipotesis berikut:

H2 Kewajaran harga memiliki pengaruh yang signifikan terhadap kepuasan pelanggan

Berdasarkan pengembangan uraian hipotesis, didapatkan model penelitian sebagai berikut:

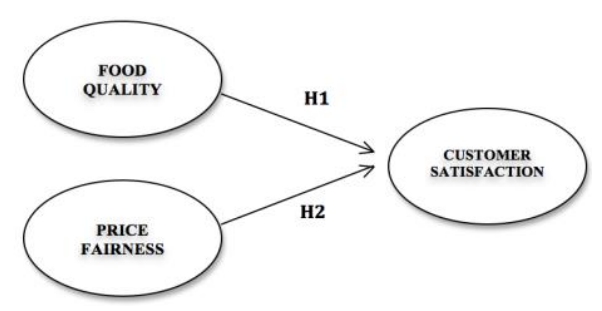

\section{Metode Penelitian}

Dalam penelitian ini, peneliti memilih pengambilan sampel menggunakan teknik non probability dengan desain sampel purposive sampling karena pengambilan sampel responden diambil dari populasi objek penelitian yang merupakan masyarakat kalangan milenial dengan rentan usia 18 - 38 tahun. Pemilihan objek yang akan dipilih mewakili objek yang akan dipelajari. Berdasarkan pemaparan teori tersebut, populasi penelitian ini yakni generasi Milenial Restoran XYZ, Alam Sutera dengan rentan usia 18-38 tahun. Menurut (Likert, 1932) penelitian menggunakan lima alternatif dalam pilihan jawaban kuesioner, maka perlu menggunakan nilai dari 1 - 5 dengan nilai tiga sebagai jawaban netral. Penelitian ini terbagi dalam tiga variabel dengan indikatornya. Variabel pertama terdiri dari enam indikator pertanyaan mengenai kualitas makanan, kemudian variabel kedua terdiri dari empat indikator pertanyaan mengenai indikator kewajaran harga, dan variabel ketiga terdiri dari enam pertanyaan indikator mengenai kepuasan pelanggan yang didistribusikan secara online melalui google form dan mendapatkan respon sebanyak 229. Dengan jawaban responden yang valid sebanyak 200 respon.

Bagian pertama dari kuesioner ini merupakan profil dari masing-masing responden dan bagian kedua merupakan indikator-indikator yang berkaitan dengan variabel yang diuji, yaitu; Kualitas Makanan, Kewajaran Harga, dan Kepuasan Pelanggan. Indikator dari kualitas makanan diadopsi dari penelitian (Jalal Hanaysha, 2016) indikator dari kewajaran harga diadopsi dari berbagai penelitian (Xia et al., 2004; Bolton et al., 2003; Briesch et al., 1997; (Jalal Hanaysha, 2016) dan indikator kepuasan pelanggan diadopsi dari penelitian (Dutka, 2008; Hariyanto, 2017). Penelitian ini menggunakan skala likert poin dengan 1 = Sangat Tidak Setuju, $2=$ Tidak Setuju, $3=$ Netral, $4=$ Setuju, dan $5=$ Sangat Setuju. Analisis statistik menggunakan program SPSS versi 25.0.

\section{Hasil dan Pembahasan}

Tabel 1. Profil Responden

\begin{tabular}{|c|c|c|c|c|}
\hline \multirow{2}{*}{$\begin{array}{l}\text { No } \\
1 \\
\end{array}$} & \multirow{2}{*}{$\begin{array}{c}\text { Pertanyaan } \\
\text { Jenis Kelamin } \\
\end{array}$} & \multirow{2}{*}{$\begin{array}{c}\text { Jawaban } \\
\text { Pria } \\
\end{array}$} & \multicolumn{2}{|c|}{ Erequensi Persentase } \\
\hline & & & 78 & $39 \%$ \\
\hline & & Wanita & 22 & $61 \%$ \\
\hline \multirow[t]{3}{*}{2} & Umur & $18-24$ & 86 & $93 \%$ \\
\hline & & $25-31$ & 10 & $5 \%$ \\
\hline & & $32-38$ & 4 & $2 \%$ \\
\hline \multirow[t]{4}{*}{3} & Wilayah Tempat Tinggal & Jakarta & 69 & $34.5 \%$ \\
\hline & & Kota Tangerang & 61 & $30.5 \%$ \\
\hline & & Kota Tangsel & 40 & $20 \%$ \\
\hline & & Kab. Tangerang & 30 & $15 \%$ \\
\hline \multirow[t]{5}{*}{4} & Pekerjaan & Pelajar/Mhs & 68 & $84 \%$ \\
\hline & & Swasta & 16 & $8 \%$ \\
\hline & & Wiraswasta & 14 & $7 \%$ \\
\hline & & Fashion Designer & 1 & $0.5 \%$ \\
\hline & & Guru & 1 & $0.5 \%$ \\
\hline \multirow[t]{5}{*}{5} & Rata-rata pengeluaran Makan & $\mathrm{n}<\mathrm{Rp} 50.000$ & 12 & $6 \%$ \\
\hline & & Rp50.001-Rp100.000 & 95 & $47.5 \%$ \\
\hline & & Rp100.001-Rp200.000 & 067 & $33.5 \%$ \\
\hline & & Rp250.001-Rp500.000 & $0 \quad 19$ & $9.5 \%$ \\
\hline & & $>\operatorname{Rp} 500.000$ & 7 & $3.5 \%$ \\
\hline
\end{tabular}

Sumber : Hasil Olahan Data (2020).

Dengan total responden sebanyak 200, dapat dikatakan bahwa profil responden mayoritas berjenis kelamin perempuan dengan jumlah 122 responden $(61 \%)$ sedangkan jumlah responden laki-laki berjumlah 78 responden (39\%). Berdasarkan hasil survey menunjukkan usia 18-24 tahun yang mencapai 186 responden (93\%), untuk umur 25-31 tahun 
sebesar 10 responden (5\%), untuk umur 32-38 tahun sebesar 4 responden (2\%). Wilayah tempat tinggal responden, mayoritas responden berdomisili di Jakarta dengan jumlah 69 responden $(34.5 \%)$, yang kedua tertinggi yakni berdomisili di Kota Tangerang dengan jumlah 61 responden $(30.5 \%)$, disusul dengan responden yang berdomisili Kota Tangerang Selatan dengan 40 responden (20\%), yang terakhir responden yang berdomisili di Kabupaten Tangerang yakni ada 30 responden $(15 \%)$.

Responden yang berdomisili di Jakarta memiliki peringkat tertinggi pertama dan disusul oleh Kota Tangerang sebagai peringkat kedua. Dari tabel diatas menjelaskan responden sebagai pelajar atau mahasiswa sebanyak 168 responden (84\%), pegawai swasta menduduki jumlah sebanyak 16 responden (8\%), diikuti wiraswasta sebesar 14 responden (7\%), fashion designer sebanyak 1 responden $(0.5 \%)$ dan yang terakhir ada nya guru sebanyak 1 responden $(0.5 \%)$. Pengeluaran rata-rata ketika makan disebuah Restoran, terlihat responden dengan pengeluaran < Rp. 50.000,00 ada berjumlah 12 responden (6\%), kedua tertinggi ada pengeluaran Rp. 50.001,00 - Rp. 100.000,00 dengan jumlah 95 responden $(47.5 \%)$, diikuti dengan pengeluaran Rp. 100.001,00 - Rp. 200.000,00 dengan jumlah 67 responden (33.5\%), pengeluaran Rp. 200.001,00 - Rp. 500.000,00 dengan jumlah 19 responden (9.5\%), pengeluaran > Rp. 500.000,00 dengan jumlah 7 responden (3.5\%). Berdasarkan hasil olahan data maka dapat diketahui bahwa mayoritas pengeluaran rata-rata responden sebanyak Rp. 50.001,00 - Rp. 100.000,00 dengan jumlah tertinggi sebanyak 95 responden $(47,5 \%)$ ketika makan disebuah restoran, diikuti kedua tertinggi rata-rata responden sebanyak Rp. 100.001,001 - Rp. 200.000,00 dengan jumlah 67 responden (33.5\%) ketika makan disebuah restoran.

Dalam penelitian ini, peneliti melakukan pengukuran melalui pengujian validitas dan pengujian reliabilitas untuk mengetahui nilai signifikan dari pengujian tersebut. Pengujian validitas menurut (Sekaran \& Bougie, 2016) didasari pada pengambilan keputusan jika $r$ hitung $\geq \mathrm{r}$ tabel, maka setiap pertanyaan valid, dan jika $r$ hitung $\leq$ (lebih kecil) dari $r$ tabel maka setiap pertanyaan tersebut tidak valid. Sedangkan pada pengujian reliabilitas dapat dikatakan reliabel jika suatu variabel memiliki nilai Cronbach's Alpha $>0.6$ (Sekaran \& Bougie, 2016).

Berikut adalah hasil penghitungan Pearson Corelation untuk indikator variabel kulaitas makanan (FQ) dengan pencapaian nilai Q1 bernilai 1, Q2 bernilai $0.368, \mathrm{Q} 3$ dengan nilai 0.365 , Q4 dengan nilai 0.425 , Q5 dengan nilai 0.465 dan Q6 dengan nilai 0.440. pencapaian nilai nilai tersebut melebihi nilai $r$ tabel sebasar 0.1388 sehingga semua indikator pertanyaan untuk kualitas makanan dinyatakan valid. Sedangakan untuk indikator pertanyaan kewajaran harga atau (FP) dengan pencapaian nilai pada perhitungan pearson correlation sebagai berikut: FP 1 mencapai nilai $1, \mathrm{FP} 2$ dengan nilai $0.016, \mathrm{FP} 3$ dengan nilai 0.424 dan FP5 dengan nilai 0.454. dari hasil nilai-nilai tersebut melebihi nilai $r$ tabel sebesar sebesar 0.1388 maka indikator pertanyaan untuk variabel kelayakan harga dinyatakan valid.selanjutnya untuk indikatorvariabel kepuasan $(\mathrm{S})$ berturut turut mendapatkan nilai S1 dengan nilai 1, S2 dengan nilai $0.468, \mathrm{~S} 3$ dengan nilai 0.383 , S4 dengan nilai 0.468 , S5 dengan nilai 0.495 dan nilai S6 adalah 0.495 maka pertanyaan indikator variabel Kepuasan dinyatakan valid karena melampaui niai $\mathrm{r}$ tabel yaitu 0.1388 .

Pada tabel kedua pengujian reliabilitas dari setiap variabel yang diteliti mendapatkan nilai Cronbach's Alpha yang lebih besar dari 0.06. Sehingga dapat dikatakan bahwa setiap indikator penelitian reliabel dan konsisten.

Tabel 2. Hasil Pengujian Reliabilitas

\begin{tabular}{llccc}
\hline No & Indikator & Cronbach's alpha & $\begin{array}{c}\text { Cronbach alpha } \\
\text { Based on Std Items }\end{array}$ & N of Items \\
\hline 1 & Kualitas Makanan & 0.774 & 0.774 & 4 \\
\hline 2 & Kewajaran Harga & 0.774 & 0.774 & 4 \\
\hline 3 & Kepuasan Pelanggan & 0.845 & 0.845 & 6 \\
\hline
\end{tabular}

Sumber : Hasil Olahan Data (2020).

\section{Model Struktural}

Dalam model struktural peneliti menggunakan pengujian koefisien determinasi $\left(\mathrm{R}^{2}\right)$, analisis regresi berganda, pengujian asumsi klasik, dan pengujian hipotesis. Nilai pengujian koefisien determinasi $\left(\mathrm{R}^{2}\right)$ harus berada di antara nol dan satu $\left(0 \leq \mathrm{R}^{2} \geq 1\right)$. Jika nilainya mendekati satu, maka variabel bebas hampir dapat menjelaskan semua informasi yang dibutuhkan untuk dapat memprediksi variabel terikat secara simultan. Dasar pengukuran analisis regresi linier berganda dapat dilihat 
dari nilai signifikan atau Fhitung. Analisis regresi linier berganda dapat dikatakan berpengaruh simultan jika memiliki nilai sig lebih dari 0.05 atau nilai Fhitung lebih besar dari nilai Ftabel. Pengujian asumsi klasik terdiri dari 4 pengujian, yaitu uji normalitas yang bertujuan untuk menguji sebuah distribusi model regresi, variabel independen dan variabel dependen untuk mendeteksi residual berdistribusi normal atau tidak. Dasar pengambilan keputusan sebuah data dapat dikatakan berdistribusi normal jika nilai signifikan menggunakan uji Monte Carlo lebih dari 0.05. akan tetapi jika nilai signifikan yang diperoleh lebih kecil dari 0.05 maka data tersebut dapat dikatakan tidak terdistribusi secara normal.

Kedua adalah uji multikolinearitas yang dapat dilihat dari nilai inflasi varians (VIF) $<10.00$ dan nilai toleransi $>0.100$. Jika nilai inflasi varians (VIF) $<10.00$ dan nilai toleransi >0.100, maka hasil tersebut memuaskan sehingga variabel independen dapat digunakan untuk dianalisis dan tidak terjadi multikolinearitas. Ketiga adalah uji heteroskedastisitas bertujuan untuk menguji apakah terjadi ketidaksamaan varians residual dari satu pengamatan ke pengamatan lain di dalam sebuah model regresi berdasarkan teori (Ghozali, 2018). Pengujian heteroskedastisitas dapat dilihat menggunakan teori dari uji Glejser, yang menyatakan jika nilai signifikansi < 0,05 maka terjadi heteroskedastisitas, sedangkan jika nilai signifikansi $>0,05$ maka tidak terjadi heteroskedastisitas. Keempat adalah uji autokorelasi, menurut (Ghozali, 2018) model regresi yang baik adalah model regresi yang bebas dari autokorelasi sehingga residual tidak terdapat hubungan korelasi yang disebut dengan residual yang acak. Tidak ada gejala autokorelasi, jika nilai Durbin Watson terletak antara du sampai dengan (4-du).

Berdasarkan tabel tiga, didapatkan hasil dari pengujian koefisien determinasi $\left(\mathrm{R}^{2}\right)$ dari nilai adjusted R Square sebesar 0.626 atau $62.6 \%$. Hal ini menunjukkan bahwa kepuasan pelanggan dapat dijelaskan sebesar $62.6 \%$ oleh variabel independen yaitu kualitas makanan dan kewajaran harga. Sedangkan $37.4 \%$ variasi kepuasan pelanggan dijelaskan oleh variabel-variabel diluar variabel independen penelitian ini.

Tabel 3. Hasil Pengujian Koefisien Determinasi

\begin{tabular}{|c|c|c|}
\hline Model $\mathrm{R}$ & 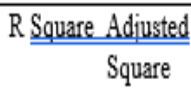 & $\begin{array}{l}\text { Std error o. } \\
\text { Estimate }\end{array}$ \\
\hline $0.794^{2}$ & $0.630 \quad 0.626$ & 1.804322 \\
\hline
\end{tabular}

Sumber : Hasil Olahan Data (2020).

Pada tabel empat, menunjukan tabel dari hasil pengujian analisis regresi berganda. Didapatkan Fhitung 167.868 yang lebih besar dari Ftabel sebesar 3.04. Hal ini didukung dengan nilai Sig sebesar 0.000 yang lebih kecil dari 0.05. Maka dapat disimpulkan terdapat pengaruh yang signifikan antara kualitas makanan dan kewajaran harga terhadap kepuasan pelanggan.

\section{Tabel 4. Hasil Pengujian Analisis Regresi} Berganda

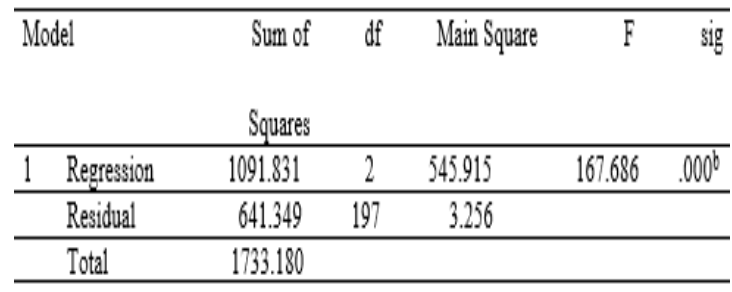

Sumber : Hasil Olahan Data (2020)

Tabel 5. Hasil Pengujian Normalitas One- Sample Kolmogorov-Smirnov Test

\begin{tabular}{|c|c|c|}
\hline \multicolumn{3}{|c|}{ Unstandardized Residual } \\
\hline $\mathrm{N}$ & & 200 \\
\hline \multirow[t]{2}{*}{ Normal Parameters sb $^{2}$} & Mean & .0000000 \\
\hline & Std Deviation & 1.79523279 \\
\hline \multirow[t]{3}{*}{ Most Extreme Differences } & Absolute & 0.96 \\
\hline & Positive & 0.46 \\
\hline & Negative & .0 .96 \\
\hline Test Statistic & & 0.096 \\
\hline Asymp.Sig. (2-tailed) & & $.000^{\circ}$ \\
\hline Monte Crarlo Sig. (2-tailed) & Sig & $0.060^{d}$ \\
\hline & 95\% Confidence Interval Lower bound & 0.027 \\
\hline & Upper bound & 0.093 \\
\hline
\end{tabular}

Sumber : Hasil Olahan Data (2020).

Berdasarkan tabel lima memperlihatkan hasil dari pengujian normalitas menggunakan Monte Carlo dan didapati hasil sebesar 0.06 yang lebih besar dari 0.05. Sehingga dapat disimpulkan bahwa data yang digunakan berdistribusi normal dan memenuhi asumsi normalitas.

Berdasarkan tabel enam didapatkan hasil pengujian multikolinearitas dengan nilai 
tolerance sebesar 0.579 untuk variabel kualitas makanan dan kewajaran harga > atau lebih besar dari 0.100 dan didukung oleh nilai VIF sebesar 1.727 yang < atau lebih kecil dari 10.00. Sehingga disimpulkan bahwa variabel independen yaitu kualitas makanan dan kewajaran harga dapat digunakan untuk dianalisis dan tidak terjadi multikolinearitas.

Tabel 6. Hasil Pengujian Multikolinearitas

\begin{tabular}{|c|c|c|c|c|c|c|}
\hline Model & $\begin{array}{c}\text { Unstd } \\
\text { B }\end{array}$ & $\begin{array}{l}\text { Coefficient } \\
\text { Std Error }\end{array}$ & $\begin{array}{l}\text { Std } \\
\text { coef. beta }\end{array}$ & $\mathrm{t}$ & $\frac{\text { sig Collinearity }}{\text { Tolerance }}$ & $\begin{array}{l}\text { Statistic } \\
\text { VIF }\end{array}$ \\
\hline 1 (Constant) & 2.834 & 1.316 & & 2.153 & .033 & \\
\hline \multicolumn{2}{|c|}{ Kualitas Makanan_619 } & .061 & .577 & 10.125 & 5.000 & 1.727 \\
\hline Kewajaran & $\begin{array}{ll}\text { rga } & .425\end{array}$ & .084 & .287 & 5.044 & 4,000 & 1.727 \\
\hline
\end{tabular}

Sumber : Hasil Olahan Data (2020).

Berdasarkan tabel tujuh didapatkan nilai uji glejser yang menunjukkan bahwa kualitas makanan dengan nilai signifikansi 0.337 dan kewajaran harga dengan nilai signifikansi 0.168 . Sehingga dapat disimpulkan nilai signifikansi kualitas makanan $0.337<0.5$, maka terjadi heteroskedastisitas. Kewajaran harga juga memiliki nilai $0.168<0.5$ maka variabel kewajaran harga juga terjadi heteroskedastisitas.

Tabel 7. Hasil Pengujian Heteroskedastisitas

\begin{tabular}{lccccc}
\hline Model & \multicolumn{2}{c}{ Unstandardized Coefficient } & Standardized & $\mathrm{t}$ & sig \\
& $\mathrm{B}$ & Std Error & Coefficient beta & & \\
\hline 1 1_Constant) & 3.750 & .894 & & 4.196 & .000 \\
& & & & & \\
\hline Kualitas Makanan & -.040 & .042 & .088 & -.963 & .337 \\
& & & & & \\
\hline Kewajaran Harga & -.079 & .057 & -.127 & -1.382 & .168
\end{tabular}

Sumber : Hasil Olahan Data (2020).

Pada tabel delapan didapatkan hasil dari uji autokorelasi sebesar 2.089 yang dilihat dari nilai Durbin Watson. Nilai tersebut lebih dari du yakni sebesar 1.7887 dan lebih kecil dari nilai 4-du yakni sebesar 2.212. Berdasarkan Konstanta atau banyaknya variabel X (dua) dan $n$ atau jumlah responden (200) dengan signifikansi $5 \%$. Berdasarkan hal tersebut dapat disimpulkan bahwa tidak didapati gejala autokorelasi di dalam variabel yang diuji peneliti.
Tabel 8. Hasil Pengujian Autokorelasi

\begin{tabular}{cccccc}
\hline Model & $\mathrm{R}$ & $\mathrm{R}$ Square & $\begin{array}{c}\text { Adjusted } \\
\text { Square }\end{array}$ & $\begin{array}{cccc}\text { Std Error of } \\
\text { the Estimate }\end{array}$ & $\begin{array}{l}\text { Durbin } \\
\text { Watson }\end{array}$ \\
\hline 1 & $.794^{4}$ & .630 & .626 & 1.804 & 2.089 \\
\hline
\end{tabular}

Sumber : Hasil Olahan Data (2020)

Pengujian hipotesis merupakan uji dari kesimpulan sementara yang dilakukan untuk mengetahui ada atau tidaknya pengaruh yang signifikan antara variabel, yaitu variabel $\mathrm{x}$ (independen) dengan variabel y (dependen), yang terdiri dari Uji $F$ dan Uji t. Uji $F$ digunakan untuk mengetahui apakah variabel independen yang digunakan dalam model penelitian mempunyai pengaruh terhadap variabel dependen jika nilai signifikan $<0.05$, maka variabel independen $(\mathrm{X})$ secara parsial berpengaruh terhadap variabel dependen $(\mathrm{Y})$. Sedangkan uji t digunakan untuk menunjukan seberapa jauh pengaruh variabel independen terhadap variabel dependen secara parsial, dengan analisis jika nilai signifikan $<0.05$ maka variabel independen (X) secara parsial berpengaruh terhadap variabel dependen $(\mathrm{Y})$. Berdasarkan tabel 9 dapat dilihat bahwa hasil pengujian $\mathrm{F}$ memiliki nilai signifikan sebesar 0.000 yang lebih kecil dari 0.05 . Didukung dengan hasil Fhitung $167.686>$ Ftabel 3.04, maka Ho ditolak dan Ha diterima yang berarti variabel independen $(\mathrm{X})$ berpengaruh terhadap variabel dependen ( $\mathrm{Y}$ ) sehingga dapat disimpulkan bahwa kedua variabel independen, yaitu kualitas makanan dan kewajaran harga berpengaruh secara parsial terhadap variabel dependen, yaitu kepuasan pelanggan.

\section{Tabel 9. Hasil Uji F}

\begin{tabular}{|c|c|c|c|c|}
\hline Model & Sum of square df & Mean square & $\mathrm{F}$ & Sig \\
\hline 1 Regression & $1091.831 \quad 2$ & 545.915 & 167.686 & $.000^{\mathrm{b}}$ \\
\hline Residual & 641.349 & 3.156 & & \\
\hline Total & 1733.180 & & & \\
\hline
\end{tabular}

Sumber : Hasil Olahan Data (2020)

Pada tabel 10 yang merupakan hasil dari uji t, hasil dari pengujian $t$ dapat dilihat dari nilai signifikan variabel independen yaitu, kualitas makanan sebesar 0.000 dan kewajaran harga sebesar 0.000 yang memiliki nilai lebih kecil dari 0.05. Jika |thitung| dengan hasil 2.153 > ttabel dengan hasil 0,67574, maka Ho ditolak dan Ha diterima yang berarti variabel independen $(X)$ berpengaruh terhadap variabel dependen (Y). Oleh karena itu dapat 
disimpulkan bahwa kedua variabel independen yaitu, kualitas makanan dan kewajaran harga memiliki pengaruh parsial terhadap variabel dependen, yaitu kepuasan pelanggan.

\section{Tabel 10. Hasil Uji t}

\begin{tabular}{|c|c|c|c|c|c|c|c|}
\hline Model & $\begin{array}{c}\text { Unstandardizec } \\
\text { B } \\
\end{array}$ & $\begin{array}{l}\text { Coefficien } \\
\text { Std Error }\end{array}$ & $\begin{array}{l}\text { Standardized } \\
\text { coefficient beta }\end{array}$ & t & & $\begin{array}{l}\text { collinearity } \\
\text { tolerance }\end{array}$ & $\begin{array}{l}\text { statistic } \\
\text { VIF }\end{array}$ \\
\hline 1 (Constant) & 2.834 & 1.316 & & 2.153 .0 & .033 & & \\
\hline Kualitas Makane & an $\quad .619$ & .061 & .577 & 10.125 & 0000 & .579 & 1.727 \\
\hline Kewajaran Harg & .425 & .084 & .287 & 5044 & 000 & .579 & 1.727 \\
\hline
\end{tabular}

Sumber : Hasil Olahan Data (2020)

Hasil dari hipotesis pertama atau H1, yaitu Kualitas Makanan terbukti memberikan pengaruh terhadap Kepuasan Pelanggan. Bahwa kepuasan pelanggan generasi milenial Restoran Ikkudo Ichi Alam Sutera dipengaruhi oleh kualitas makanan yang diberikan Restoran selama masa pandemi COVID-19. Hal ini juga dibuktikan dengan penelitian yang telah dilakukan oleh (Yuliantoro et al., 2019)yang menyatakan adanya pengaruh signifikan variabel kualitas makanan terhadap variabel kepuasan pelanggan dan juga penelitian (Ehsani \& Ehsani, 2015) yaitu kualitas produk memainkan peran kunci dalam daya saing perusahaan dengan mempengaruhi kepuasan pelanggan, kualitas produk telah diakui juga sebagai penentu dari sebuah perilaku pembelian dan kepuasan pelanggan yang ditentukan oleh kinerja dan ekspektasi, yang juga akan berdampak kepada kesuksesan perusahaan.

Kemudian hasil dari hipotesis kedua atau H2, yaitu Kewajaran Harga yang memberikan pengaruh terhadap Kepuasan Pelanggan. Terbukti bahwa nilai yang dikorbankan untuk mendapatkan suatu produk dengan manfaat yang didapatkan dari produk tersebut mempengaruhi kepuasan dari pelanggan generasi milenial Restoran Ikkudo Ichi di Alam Sutera selama masa pandemi COVID-19. Hasil ini didukung dengan penelitian yang dilakukan oleh (Yuliantoro et al., 2020), "kewajaran harga secara parsial berpengaruh positif terhadap kepuasan pelanggan." dan penelitian yang dilakukan oleh (J Hanaysha, 2016) bahwa kewajaran harga memiliki berpengaruh terhadap kepuasan pelanggan secara positif dan signifikan.

\section{Simpulan}

Berdasarkan analisa data tentang Pengaruh Kualitas Makanan dan Kewajaran Harga terhadap Kepuasan Pelanggan Generasi Milenial di Restoran XYZ Alam Sutera Selama Masa Pandemi COVID-19 dapat disimpulkan bahwa:

Kualitas makanan memiliki pengaruh signifikan terhadap kepuasan pelanggan dengan begitu maka Ha1 diterima yang berarti adanya pengaruh variabel independen (X) terhadap variabel dependen (Y).

Kewajaran harga memiliki pengaruh signifikan terhadap kepuasan pelanggan, maka $\mathrm{Ha} 2$ diterima yang berarti adanya pengaruh variabel independen $(\mathrm{X})$ terhadap variabel dependen (Y).

Implikasi Manajerial dari penelitian ini, hendaknya pihak pengelola penyedia jasa makanan dan minuman selalu konsisten dalam menjaga kualiatas makanan yang ditawarkan kepada konsumen dan memperhatikan harga makanan ditawarkan mempunyai value yang sesuai dengan ekspektasi pelanggan. Penelitian ini mempunyai keterbatasan pada variabel kualitas makanan dan kelayakan harga sehingga tidak menutup kemungkinan untuk dikembangkan dengan variabel lain yang lebih konprehensif dalam melihat kepuasana pelanggan dengan objek jenis restoran kelas menengah keatas.

\section{Daftar Pustaka}

Chamhuri, N., \& Batt, P. (2015). Consumer perceptions of food quality in Malaysia. British Food Journal, 117, 1168-1187. https://doi.org/10.1108/BFJ-08-20130235

Ehsani, Z., \& Ehsani, M. H. (2015). Effect of quality and price on customer satisfaction and commitment in Iran auto industry. International Journal of Flexible Manufacturing Systems, 3(3-4), 251-274.

Ghozali. (2018). Aplikasi Analisis Multivariate dengan Program IBM SPSS 25. Badan Penerbit Universitas Diponegoro.

Hanaysha, J. (2016). Restaurant Location and Price Fairness as Key Determinants of Brand Equity: A Study on Fast Food Restaurant Industry. Business and 
Economic Research, 6, 310-323.

Hanaysha, Jalal. (2016). Testing the Effects of Food Quality, Price Fairness, and Physical Environment on Customer Satisfaction in Fast Food Restaurant Industry. Journal of Asian Business Strategy, 6, 31-40. https://doi.org/10.18488/journal.1006/20 16.6.2/1006.2.31.40

Hariyanto, K. (2017). Analisa Pengaruh Service Quality, Food Quality Dan Perceived Value Terhadap Customer Loyalty Konsumen Restaurant Boncafe Manyar Kertoarjo Surabaya Dengan Customer Satisfaction Sebagai Variable Intervening. Jurnal Strategi Pemasaran, 4(1).

Hirschberg, C., Rajko, A., Schumacher, T. \& Wrulich, M. (2016). The changing market of food delivery.

Howe, N \& Strauss, W. (2000). Millennials Rising: The Next Great Generation, Vintage.https://doi.org/https://doi.org/10 .1037/a0027408

Lien, C.-H., Wen, M.-J., Huang, L.-C., \& Wu, K.-L. (2015). Online hotel booking: The effects of brand image, price, trust and value on purchase intentions. Asia Pacific Management Review, 20(4), 210-218. https://doi.org/https://doi.org/10.1016/j. apmrv.2015.03.005

Likert, R. (1932). A Technique for the Measurement of Attitudes, Archives of Psychology (Vol. 140).

Nicola, M., Alsafi, Z., Sohrabi, C., \& Kerwan, A. (2020). The socio-economic implications of the coronavirus pandemic (COVID-19).

Quang, N., M., N. T., Dan, K., \& Prakash, P. G. (2018). Understanding customer satisfaction in the UK quick service restaurant industry: The influence of the tangible attributes of perceived service quality. British Food Journal, 120(6), 1207-1222.
https://doi.org/10.1108/BFJ-08-20170449

Rothenberger, S. (2015). Fairness through transparency: The influence of price transparency on consumer perceptions of price fairness. Work. Pap. CEB, 15, 137.

Sekaran, U., \& Bougie, R. (2016). Research methods for business: A skill building approach (7th Editio). John Wiley \& Sons.

Sjahroeddin, F., \& Administrasi, J. (2018). The Role of E-S-Qual and Food Quality on Customer Satisfaction in Online Food Delivery Service.

Yeo, V. C. S., Goh, S.-K., \& Rezaei, S. (2017). Consumer experiences, attitude and behavioral intention toward online food delivery (OFD) services. Journal of Retailing and Consumer Services, 35, 150-162.

https://doi.org/https://doi.org/10.1016/j.j retconser.2016.12.013

Yuliantoro, N., Goeltom, V., Bernarto, I., Pramono, R., Purwanto, A., \& Juliana, J. (2019). Repurchase intention and word of mouth factors in the millennial generation against various brands of Boba drinks during the Covid 19 pandemic. African Journal of Hospitality Tourism and Leisure, 8, 1-11.

Yuliantoro, N., Goeltom, V., Bernarto, I., Pramono, R., Purwanto, A., \& Juliana, J. (2020). Z Generation Satisfaction toward Food Street Culinary at the time of Covid 19 Pandemic. International Journal of Advanced Science and Technology, 29, 5014-5023. 